\title{
The Effect Of Academic Qualification, Work Experience And Work Motivation Towards Primary School Principal Performance
}

\author{
Salwa, Muhammad Kristiawan, Bukman Lian
}

\begin{abstract}
This paper aimed at determining the influence of academic qualifications, work experience and work motivation of teachers towards the principals' performance. This research was carried out in Primary Schools in Kalidoni, Palembang. The paper used the partial correlation method. The sample in this study were 28 primary school principals in Kalidoni. The instrument in this study was questionnaire. The results of this study indicate there was significant effect of the principal's academic qualifications on the principal's performance, where $t_{\text {count }} 4,584 \geq t_{\text {table }} 2,055$; there was significant influence of work experience on the principal's performance where $t_{\text {count }} 11,360 \geq t_{\text {table }} 2.055$; there was significant effect of work motivation on the principal's performance where $t_{\text {count }} 6,564 \geq t_{\text {table }} 2,055$; and there was significant effect jointly between academic qualifications, work experience and work motivation on the principal's performance, where the ANOVA test obtained $F_{\text {count }} 155,189 \geq F$ table 3.24 . It can be concluded that there was significant influence of academic qualifications, work experience and work motivation towards the principal's performance of primary school in Kalidoni.
\end{abstract}

Index Terms:Academic Qualifications, Motivation, Work Experience, Principal Performance

\section{INTRODUCTION}

Thhis tudy was preceded by the research conducted by Djafar and Nurhazifah (2018) that the motivation of a leader in this case the principal is very needed and plays a role for teachers and employees to work together and carry out their duties responsibly and optimally good performance. Based on these results, it can be concluded that the principal's motivation influences the performance of teachers and employees. Then the research conducted by Mulyani (2012) states that the principal's performance had a positive and significant influence on the quality of learning. The dimensions of the principal's performance that gives a significant influence are aspects of ability and motivation. The performance of principals as measured by the quality of school learning has significant influence on the high and low quality of school learning (Andriani et al, 2018). This means that the level of quality of school learning is explained by the performance of the principal. Thus it is clear that the principal's performance significantly influences the quality of learning. According to Miarso (2008) qualified teachers are teachers who meet the standards of educators, master the content of the lesson in accordance with the standards of the learning process. Thus, qualifications mean the requirements that must be met are related to the abilities needed to carry out a job. Qualifications can show someone's credibility in carrying out their work. Qualifications can also be interpreted as competencies that a person must have in carrying out his duties. The principal is one of the determinants of the success of every education effort. The performance of the principal in planning and implementing learning is a major factor in achieving success in school (Tobari et al, 2018). Narrowly can be interpreted as a facilitator for the school, besides being responsible for improving the quality of education (Irmayani et al, 2018). School principals have heavy duty and responsibility, so ideally the principal must have adequate academic qualifications, work experience and positive work motivation (Putra, 2017) (Kristiawan et al, 2019) (Murtiningsih et al, 2019).

- Salwa,Muhammad Kristiawan, Bukman Lian

- Correspondence Author: muhammadkristiawan@unib.ac.id
Purwanto (2001) says that the quality of education and teaching in schools is influenced by the educational background of the principal, which means that the higher the level of education of a school principal, the higher and better the quality of education and teaching received by the learner and the higher the degree of the community. The principal is an educational leader who must have a strong leadership (Mulyasa, 2011). The principal is the most influential component in creating quality education processes and outcomes. Therefore to improve the quality of education will not provide a significant contribution without being supported by a professional and qualified headmaster of the Minister of National Education Regulation No. 13 of 2007 concerning Standard Principals with 5 (five) competencies are Personality, Managerial, Entrepreneurship, Supervision and Social. The principal in his work activities must be qualified and tested for his qualifications. The work experience according to Nitisemito (2009) is defined as something or ability possessed by employees in carrying out the tasks assigned to him. With quite a long experience and quite a lot, it is expected that they will have a greater ability than those without experience. People who are experienced in work have better work ability than people who have just entered the workforce, because the person has learned from the activities and problems that arise in his work. With the existence of work experience, there has been a process of adding knowledge and skills and attitudes to a person, so that they can support developing themselves with existing changes. The experience of a person has a very valuable value for his career interests in the future (Syafarudin, 2009). Then, Hasibuan (2000) states that work experience includes the number of types of jobs or positions that have been occupied by someone and the length of time they work for each job or position. According to Kunandar (2007) work experience is the period of work in carrying out tasks as educators in certain educational units in accordance with the assignment letter from the authorized institution. Sujiono (2010) also states that work experience is in the form of a period of work that has been carried out by the teacher, a collection of learning plans made, and awards achieved. Employees can be said to have work experience if they have done work repeatedly. As for the things that determine the experience or not of an employee are as follows 1) the length 
of time or period of work size about the length of time or period of work that has been taken someone can understand the tasks of a job and have carried out well; 2) the level of knowledge and skills possessed by knowledge refers to concepts, principles, procedures, policies or other information needed by employees. Knowledge also includes the ability to understand and apply information to work responsibilities. While skills refer to the physical abilities needed to reach or carry out a task or job; 3) mastery of work and equipment the level of mastery of a person in the implementation of aspects of the technical equipment and work techniques; 4) the type of work the more types of tasks carried out by a person, generally the person will get better results of the implementation of the task (Sa'diyah, 2013). When the principal enters the workforce, he will certainly be faced with a variety of circumstances, both those that support and those that hinder the school management process. The various conditions faced by the principal will certainly encourage the principal to find a solution to overcome them (Fitria, 2018). The longer a teacher becomes a headmaster, the more principals will get useful experience. Of course the principal's experience was not only obtained when he became the principal. But also when he became a teacher. As expressed by H. Uno (2010) that teachers have a great opportunity to learn from their teaching experiences in the field rather than learning from various research and psychological approaches. Then for the work experience of a principal is certainly based on the ability of his ability, namely (1) able to lead the school; (2) able to master the method, (3) master the educational foundation; (4) plan school programs appropriately; (5) evaluating the results of school program activities, (6) applying the results of research in school implementation activities; (7) loyalty to the organization; (8) psychological attachment; (9) task involvement; (10) enthusiasm, (11) enthusiasm (Mulyadi, 2012). It is from these indicators that the principal can be considered experienced or not in managing educational institutions. If the above elements have been fulfilled and owned by a principal, then the principal can be said to be experienced. The more work experience, the performance of principals tends to be higher. Likewise, on the contrary, the less work experience, the principal's performance tends to be lower. As explained by Soetjipto (2007), that the more work experience a person has, the more benefits that will have an impact on the breadth of knowledge in the field of work and increasing one's skills. The ability of the principal is inseparable from a number of potentials, as well as mastered expertise, knowledge and work experience (Bashor, 2007). Motenary (in Akdon, 2004) also states that the work experience that a person has can support the implementation of his duties, so that he can work optimally. Based on the preliminary study, information or description was obtained that the Principal Principal in the Kalidoni area of Palembang had 19 SPG academic qualifications $(67.85 \%)$, and there were 9 Masters $(32.16 \%)$. Thus, the majority of principals in the Kalidoni of Palembang have mostly fulfilled academic qualifications. The data shows that the academic qualifications possessed by an Elementary School Principal in the Kalidoni area of Palembang have complied with Article 9 of the Teacher and Lecturer Law, which requires a headmaster to have an academic qualification for a Bachelor program or Diploma Four program. Temporary observations show signs that the academic qualifications of the principals show varying performance. Based on the explanation above, it can be said that the work experience and work motivation of the Elementary School principals in the Kalidoni area of Palembang in carrying out their daily tasks also vary greatly, long working experience also has low competence. Judging from the size of the school's success, the principal's performance can be shown in the success with regard to school management, learning activities, workforce, infrastructure, finance, school environment, and school relations with the community (Suhardi, 2012) (Lian, et al, 2018) (Renata et al, 2018) (Tobari et al, 2018) (Sarina et al, 2019) (Wandasari et al, 2019). According to Daryanto (2011) argues that the performance indicators of school principals are effective, including being able to realize an effective learning process, clearly establishing the vision and mission, and implementing effective management of education staff. Factors that influence performance achievement are factors of ability and motivation factors. The ability factor consists of factors of knowledge and skills (Keith Davis in Mangkunegara, 2004). In addition to the ability and motivation factors, other factors that can influence individual performance are organizations where the process takes place (Anwaruddin, 2006). The observations show that there are many gaps in assessing the performance of principals, including (1) the principal has not been able to manage the school well; (2) the principal has not been able to make creative and innovative breakthroughs in the field of learning leadership; (3) the principal has not been able to create security in the school environment; and (4) the principal has not been able to create a culture of a school climate that is conducive and innovative for learning and does not adhere to the goals of the school. Various performance problems faced by elementary school principals have been relatively well identified and documented, but without examining what factors influence and how these factors relate to the performance of the principal. The Minister of National Education Regulation Number 13 of 2007 concerning Standards for Competency that Principals must possess including personality, managerial, entrepreneurship, supervision, and social. Principals who have high academic qualifications in the new paradigm of education management will have a positive impact and quite fundamental changes in the renewal of the education system in schools (Mulyasa, 2009). Work experience is an event that has been experienced and borne by individuals in living their lives, especially in earning a living (Wardayati, 2008). Principals who are experienced in carrying out their main tasks, the easier it is to provide speed, convenience, accuracy and integration in providing performance services (Kamidin, 2010). The more work experience a person has, the more benefits will affect the broad knowledge horizons in the field of work and increasing one's skills (Soetjipto, 2007). Motivation can be interpreted as a basic impulse that moves a person to behave. This encouragement is in someone who moves to do something in accordance with the encouragement in him (Uno, 2010). Munandar (in Silalahi, 2007) argues that work motivation is a process in which needs encourage a person to carry out a series of activities that lead to achieving that goal. Motivation of the principal's work is nothing but a process carried out to move the principal so that their behavior can be directed towards tangible efforts to achieve predetermined educational goals (Uno, 2010). According to McDonald (in Hamalik, 2011) motivation is an energy change within the person characterized by affective arousal and anticipatory goal reaction. So work motivation is an impulse that can cause 
someone to do activities or work to achieve goals. According to Sardiman (2011) motivation originates from the word motif which is interpreted as the driving force that is in a person to carry out certain activities in order to achieve a goal. Marno (2008) defines motivation as a condition that makes motives move according to the needs of each individual. According to the Directorate General of Education Personnel of Education Quality Improvement and Education Personnel of the Ministry of National Education (Ditjen PMPTK, 2008) that in an effort to obtain the optimal benefit of evaluating the performance of principals, there are at least five aspects that can be used as assessment measures (1) quality of work); (2) Promptness (timeliness of completing work); (3) Initiative (initiative in completing work); (4) Capability (ability to complete work); (5) Communication (the ability to foster cooperation with other parties). In contrast to the opinions expressed by Bernardin and Russel (in Gomes, 2001), it gives the meaning of performance as the record of outcomes produced on a specified job function or activity during a specified time period. In this definition the emphasized aspect is about the outcome that results from the function of a particular work or activity for a certain period of time. Thus, performance only refers to a series of results obtained by an employee during a certain period and does not include the personal characteristics of the employee being assessed (Kristiawan et al, 2017). Mangkunegara (2001) states that performance is the result of work in quality and quantity achieved by an employee in carrying out his duties according to the responsibilities given to him. The high and low performance of employees is closely related to the system of awarding including payroll applied by the institution or organization where it works. While the notion of performance according to the Directorate of Education of the Directorate General of Quality Improvement of Teachers and Education Personnel of the Ministry of National Education (Dittendik Directorate General of PMPTK MONE, 2008) performance is the result of work in achieving a predetermined job requirement or requirement. Performance can be interpreted as an expression of one's potential in the form of a person's behavior or way of carrying out a task, so as to produce a product (work result) which is a manifestation of all the tasks and responsibilities of the work given to him. The discussion above is also supported by research conducted by Muzakar (2014) with the results of the study stating that (1) the ability of school principals to improve the quality of graduates has met the criteria of graduates because the principal has carried out a variety of abilities that can support the achievement of the quality improvement of graduates, both ability as educators, managers, administrators, supervisors, leaders, and innovators; (2) in its implementation, of course, requires motivation (willingness) of the Principal and all school members to realize the quality of qualified graduates; (3) the principal is able to identify various strengths, weaknesses, opportunities and threats faced by the school, so that this can be used as a reference in making various decisions concerning the improvement of the quality of graduates. In this implementation, of course, various efforts require a shared commitment from all school members to achieve graduate quality optimally at the school. Then supported by the research conducted by Sudharto (2012), which shows a significant influence between work experience on the performance of the head of the high school in ex Karisidenan Semarang. Research conducted by Silaen (2012) with the results of research which states that there is a significant influence between work experience on teacher performance. Research conducted by Rahayu (2011), with results stating that academic qualifications influence teacher performance. Simbolon's research (2012) with the results of the study showed that academic qualifications and professional competencies had a joint influence on Teacher Performance. Thus, principals who have a high level of education and sufficient working period in their fields will have the ability to look ahead in improving the development of their mentored students, as stated by Nawawi (1985). In addition, the work period and the level of education that is adequate for an educator will affect the performance that he has. Thus, it is clear, that experience is a lesson that will produce changes towards behavior maturity, increased understanding and enrichment of information. Through a lengthy working period for teachers it is expected that they can become successful education personnel in managing the classes they guide. Learning from various experiences in office, is very helpful for teachers in improving their professional abilities. Likewise with the level of education, the higher the level of education the more widespread and in the curriculum program provided and the longer the achievement period so that it will affect the ability of the objectives that take the program. If a teacher has high ability and knowledge, he is expected to be able to transfer his abilities and knowledge to improve the quality of education in schools in general and improve student achievement in particular.

\section{Research Methods}

The objectives of this study are as follows: a) To determine the effect of academic qualifications on the performance of elementary school principals in the Kalidoni of Palembang; b) To determine the effect of work experience on the performance of elementary school principals in the Kalidoni of Palembang; c) To determine the effect of work motivation on the performance of elementary school principals in Kalidoni Palembang; d) To determine the effect of simulutan academic qualifications, work experience and work motivation on the performance of elementary school principals in the Kalidoni of Palembang. This research was carried out in public elementary schools in the Kalidoni sub-district of Palembang. Because weighing the limitations of time and costs that are owned by researchers. In addition, primary schools in the Kalidoni Sub-district were chosen by researchers for several reasons, namely the school has adequate criteria for research. The time of the study was held on October 1, 2018 to June 1, 2019. This type of research is quantitative research, which is according to Musfiqon, (2012) research focused on the study of objective phenomena to be studied quantitatively. Research on data collection is carried out quantitatively. While this research method uses the method of partial correlation, partial correlation is used for analysis or testing of hypotheses if the researcher intends to know the influence or relationship of the dependent variable independently, where one of the independent variables is controlled (fixed) (Sugiyono, 2009). are all school principals in the Kalidoni of Palembang, which number 28 as follows. 
Table 1. Total Population Research (UPT of Kalidoni Palembang in 2018)

\begin{tabular}{|c|c|c|c|c|}
\hline No & Name of School & Name of Principal & Gender & $\begin{array}{c}\text { Academic } \\
\text { Qualifications }\end{array}$ \\
\hline 1 & SD N 167 Palembang & Mairowati & & \\
\hline 2 & SD N 168 Palembang & Ani Irma & & \\
\hline 3 & SD N 169 Palembang & Shopiah & & \\
\hline 4 & SD N 170 Palembang & Sri Kusminah & & \\
\hline 5 & SD N 171 Palembang & Rahayati & & \\
\hline 6 & SD N 172 Palembang & Mutibah & & \\
\hline 7 & SD N 173 Palembang & Rotosman & & \\
\hline 8 & SD N 174 Palembang & Mardiana & & \\
\hline 9 & SD N 175 Palembang & Mariani & & \\
\hline 1 & SD N 176 Palembang & Mayah & $P$ & S2 \\
\hline 0 & SD N 177 Palembang & Desilawati & $P$ & S2 \\
\hline 11 & SD N 178 Palembang & Fatmah & $P$ & S1 \\
\hline 1 & SD N 179 Palembang & Rita Murni & $\mathrm{P}$ & S2 \\
\hline 2 & SD N 180 Palembang & Nasrah & $P$ & S2 \\
\hline 1 & SD N 181 Palembang & Asniana & $P$ & S1 \\
\hline 3 & SD N 182 Palembang & Atika & L & S1 \\
\hline 1 & SD N 183 Palembang & Berliana & $\mathrm{P}$ & S1 \\
\hline 4 & SD N 184 Palembang & Habibah & $P$ & S2 \\
\hline 1 & SD N 185 Palembang & Nurleli & $P$ & S2 \\
\hline 5 & SD N 186 Palembang & Rizki M & $P$ & S1 \\
\hline 1 & SD N 187 Palembang & Rodiah & $P$ & S1 \\
\hline 6 & SD N 188 Palembang & Rukiah & $P$ & S1 \\
\hline 1 & SD N 189 Palembang & Rusmini & $P$ & S1 \\
\hline 7 & SD N 190 Palembang & Paridah & $P$ & s1 \\
\hline 1 & SD N 191 Palembang & Mariroh & $P$ & S1 \\
\hline 8 & SD N 192 Palembang & Tuti & $\mathrm{P}$ & S1 \\
\hline 1 & SD N 193 Palembang & Salwa & $P$ & S1 \\
\hline 9 & SD N 194 Palembang & Dahlia & $P$ & $\mathrm{~S} 1$ \\
\hline 2 & & & L & $\mathrm{S} 2$ \\
\hline 0 & & & $\mathrm{P}$ & $\mathrm{s} 2$ \\
\hline 2 & & & $P$ & $\mathrm{~S} 1$ \\
\hline 1 & & & $P$ & S1 \\
\hline 2 & & & $\mathrm{P}$ & S1 \\
\hline 2 & & & $P$ & S1 \\
\hline 2 & & & $P$ & $\mathrm{~S} 1$ \\
\hline 3 & & & $P$ & S1 \\
\hline 2 & & & $P$ & S2 \\
\hline \multicolumn{5}{|l|}{4} \\
\hline \multicolumn{5}{|l|}{2} \\
\hline \multicolumn{5}{|l|}{5} \\
\hline \multicolumn{5}{|l|}{2} \\
\hline \multicolumn{5}{|l|}{6} \\
\hline \multicolumn{5}{|l|}{2} \\
\hline \multicolumn{5}{|l|}{7} \\
\hline \multicolumn{5}{|l|}{2} \\
\hline \multicolumn{5}{|l|}{8} \\
\hline & Total & 28 & & \\
\hline
\end{tabular}

\subsection{Test Instrument}

\subsubsection{Validity Testing}

The validity of the instrument in this study was measured using the Product Moment formula from Pearson. The suitability of rxy prices obtained through calculations using the formula is then consulted with the Product Moment critique $r$ table with the following decision methods. If $r$ count $>r$ table, then the instrument is categorized as valid. But vice versa, when the calculation is <rabel, then the instrument is categorized as invalid and is not feasible to use data retrieval. The Pearson product moment correlation test was performed using SPSS 22.00.

\subsubsection{Reliability Testing}

Reliability testing in this study uses internal reliability tests obtained by analyzing data from a trial result with the Cronbach Alpha formula. Test criteria if the Cronbach alpha value $>r$ table value $(0.631)$ then the measuring instrument is reliable. And vice versa, if <then the gauge is not reliable. The steps to test reliability with the help of SPSS 22.00 .

\subsection{Data Analysis Technique}

Data analysis in this study used multiple linear regression analysis. Ridwan (2013) states that multiple regression is a forecasting analysis tool of the value of the influence of independent variables or more on the dependent variable. Multiple regression equation can be stated in the following statement. $Y=a+b 1 X 1+b 2 X 2+\ldots \ldots \ldots \ldots . . . b n X n$ Information: $Y=$ Subject of the dependent variable projected $X=$ Independent variable that has a certain value to predict $a=$ Constant value $b=$ Direction value as a predictor (prediction) that shows the increase value $(+)$ or decreasing $(-)$ value of (Kesumawati and Aridanu, 2017). As for research data analysis calculation techniques, researchers used SPSS 20.00 Linear Regression analyzer to determine the value of $F_{\text {count }}$ and $t_{\text {count }}$ value as a measure of data analysis in this study.

\section{Result AND DISCUSSION}

The variables examined in this study are academic qualifications (variable X1), work experience (variable X2), work motivation (variable $\mathrm{X} 3$ ) and performance of the principal (variable Y). Then this research was carried out at the Primary School in the Kalidoni, Palembang. With the number of samples in this study were 28 Elementary School Principals in the Kalidoni of Palembang. To simplify the analysis process, the data analysis process in this study uses the SPSS 22.00 For Windows program. After the questionnaire was declared valid and feasible to be used as a data collection tool, then the researcher spread the questionnaire to all research respondents, namely the head of the school in the Kalidoni of Palembang as many as 28 respondents. The questionnaire spread to respondents (samples) was conducted in February 2019 until March 2019. After the questionnaire was distributed, the researchers then performed statistical calculations to find out the results of the statistical description of the research data and the hypothesis test to find out the results of the hypothesis in this study. Before testing the hypothesis on each research variable, the researcher will first display a description of the data for each variable in this study.

\subsection{Data Description of Respondents 3.1.1 Characteristics of Age Respondents}

Table 2. Characteristics of Age-Based Respondents

\begin{tabular}{cccc}
\hline No & Gender & Jumlah & Percentage (\%) \\
\hline 1 & Man & 2 & $7,14 \%$ \\
2 & Women & 26 & $92,96 \%$ \\
\hline & Total & 28 & $100 \%$ \\
\hline
\end{tabular}

From the table above, it can be stated that of the 28 study respondents there were 2 or 7 people, $14 \%$ were male and 26 were $92.96 \%$ female. This states that most school principals are female respondents. 


\subsubsection{Characteristics of Respondents by Age}

Table 3. Characteristics of Age-Based Respondents

\begin{tabular}{cccc}
\hline No & Age & Total & Percentage $(\%)$ \\
\hline 1 & $<35$ years & 0 & $0 \%$ \\
2 & $36-44$ years & 10 & $35,71 \%$ \\
3 & $45-55$ years & 18 & $64,29 \%$ \\
4 & $>55$ years & 0 & 0 \\
\hline & Total & 28 & $100 \%$ \\
\hline
\end{tabular}

From the table above, it can be stated that respondents aged at 35 years to 44 years were 10 people or $35.71 \%$ while those aged $45-55$ years were $64.29 \%$. From the age description, it can be stated that the respondents of this study were at the ideal age to become school principals.

\subsubsection{Characteristics of Respondents Based on Latest Education}

Table 4. Characteristics of Respondents by Education

\begin{tabular}{cccc}
\hline No & Education & Total & Percentage (\%) \\
\hline 1 & Undergraduate (S1) & 19 & $67,86 \%$ \\
2 & Postgraduate (S2) & 9 & $36,41 \%$ \\
\hline \multicolumn{2}{r}{ Total } & 28 & $100 \%$ \\
\hline
\end{tabular}

From the table above, it can be stated that there were 19 respondents or $67.86 \%$ who had S1 education background while 9 respondents had $\mathrm{S} 2$ education. This states that all principals have adequate academic standards in accordance with the applicable academic standards, namely the minimum education limit is $\mathbf{S 1}$, although some of the school principals have a master's educational background.

\subsection{Data Description of Respondents}

In this variable, there are 9 indicators to find out the academic qualifications of the primary school principal in Kalidoni, namely 1) Educational background; 2) Highest Education Level; 3) working period to become the principal; 4) professional training; 5) personality competence; 6) managerial competence; 7) entrepreneurial competence; 8) supervision competence; 9) social competence. All indicators are contained in 12 questions. The results of the descriptive analysis of the variables of the primary school academic qualifications in Kalidoni are as follows.

Table 5. Descriptive Statistics Variable Academic Qualifications in Kalidoni

\begin{tabular}{|c|c|}
\hline $\begin{array}{l}\text { Valid } \\
\text { Missing }\end{array}$ & $\begin{array}{l}28 \\
0\end{array}$ \\
\hline Mean & 49.0714 \\
\hline Median & 48.0000 \\
\hline Std. Deviation & 3.44188 \\
\hline Variance & 11.847 \\
\hline Minimum & 43.00 \\
\hline Maximum & 55.00 \\
\hline
\end{tabular}

From the table above, it can be explained that the mean value is 49 median values of 48 , the standard deviation value of 3.4 minimum value of 43 and a maximum value of 55 . After displaying a description of the data of the academic qualifications of elementary school principals in Kalidoni, then the results of the variable frequency distribution of academic qualifications in Kalidoni are as follows.

Table 6. Variable Academic Qualification Data Frequency Distribution in Kalidoni

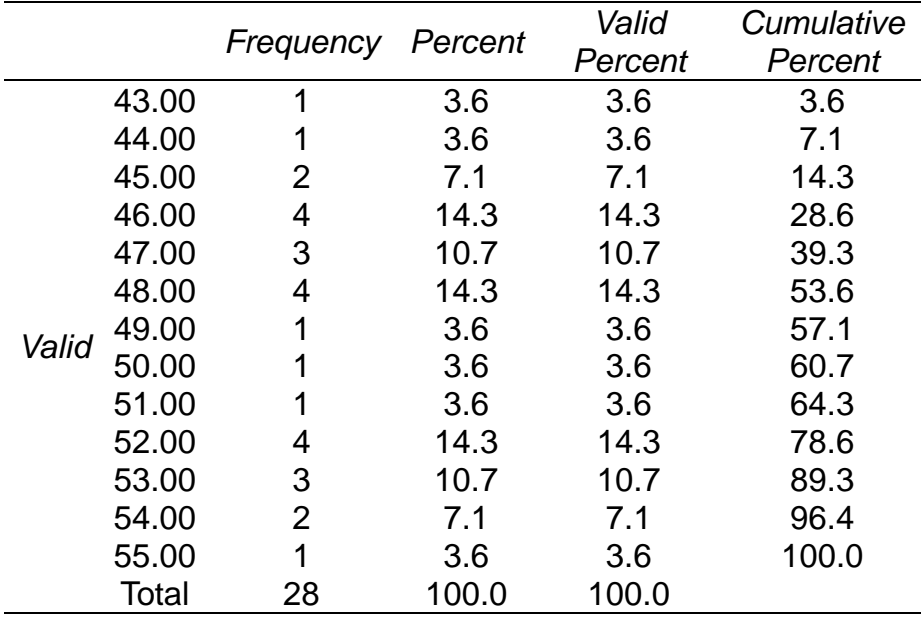

The data frequency distribution statement aims to explain the category of research respondents with very high, high, quite high, and less categories. The categorization measurement tool is to use the sum of the highest score with the number of question items. The results of categorization show that the academic qualifications of principals who have a very high category are 11 or $39.29 \%$, the high category amounts to 17 or $60.71 \%$, the category is quite high at 0 or $0 \%$, and the category is 0 or $0 \%$. As explained in the indicators of the principal's academic qualification variables in Primary Schools in the Kalidoni sub-district of Palembang are in the high category, thus the performance of the Principal has good competency in quality and quantity that is adequate to achieve the goals of the school institution towards good.

\subsubsection{Work experience at the Head of Elementary School in Kalidoni}

In this variable, there are 11 indicators to find out the experience of working in primary schools in Kalidoni, namely 1) the ability to lead schools; 2) ability to master the method; 3) ability to master the educational foundation; 4) the ability to plan school programs appropriately; 5) ability to evaluate the results of school program activities; 6) ability to apply the results of research in school implementation activities; 7) loyalty to the organization; 8) psychological attachment; 9) task involvement; 10) spirit; 11) enthusiasm / ambition. All indicators are contained in 13 questions. The results of the descriptive analysis of the basic work experience variables in Kalidoni are as follows.

Table 7. Descriptive Statistics Variable Work Experience of Elementary School Principals in Kalidoni

\begin{tabular}{|c|c|}
\hline $\begin{array}{l}\text { Valid } \\
\text { Missing }\end{array}$ & $\begin{array}{l}28 \\
0\end{array}$ \\
\hline Mean & 48.9286 \\
\hline Median & 48.0000 \\
\hline Std. Deviation & 3.21948 \\
\hline Variance & 10.365 \\
\hline Minimum & 44.00 \\
\hline Maximum & 56.00 \\
\hline
\end{tabular}


From the table above, it can be stated that the mean value is 48.9 median values of 48 , the standard deviation value of 3.2 minimum value of 44 and a maximum value of 56 . Then for the primary school primary school variable experience frequency distribution data in the Subdistrict Kalidoni is as follows.

Table 8. Frequency Distribution of Variables in Principal Work Experience in Kalidoni

\begin{tabular}{|c|c|c|c|c|c|}
\hline & & Frequency & Percent & $\begin{array}{c}\text { Valid } \\
\text { Percent }\end{array}$ & $\begin{array}{c}\text { Cumulative } \\
\text { Percent }\end{array}$ \\
\hline & 44.00 & 1 & 3.6 & 3.6 & 3.6 \\
\hline & 45.00 & 3 & 10.7 & 10.7 & 14.3 \\
\hline & 46.00 & 3 & 10.7 & 10.7 & 25.0 \\
\hline & 47.00 & 4 & 14.3 & 14.3 & 39.3 \\
\hline & 48.00 & 6 & 21.4 & 21.4 & 60.7 \\
\hline Valid & 50.00 & 1 & 3.6 & 3.6 & 64.3 \\
\hline Valla & 51.00 & 2 & 7.1 & 7.1 & 71.4 \\
\hline & 52.00 & 3 & 10.7 & 10.7 & 82.1 \\
\hline & 53.00 & 3 & 10.7 & 10.7 & 92.9 \\
\hline & 54.00 & 1 & 3.6 & 3.6 & 96.4 \\
\hline & 56.00 & 1 & 3.6 & 3.6 & 100.0 \\
\hline & Total & 28 & 100.0 & 100.0 & \\
\hline
\end{tabular}

The results of categorization show that the work experience of the principal who has a very high category is 4 or $14.28 \%$, the high category is 24 or $85.72 \%$, the category is quite high at 0 or $0 \%$, and the category is 0 or $0 \%$, and the very less category is 0 or $0 \%$. The results of the analysis indicate that the principal has good work experience in the effort to lead the school institution.

\subsubsection{Work Motivation of Elementary School Principals in Kalidoni}

In this variable, there are 9 indicators to determine the primary school motivation in Kalidoni, namely 1) Increasing teacher job satisfaction and education staff; 2) Increase work productivity; 3) Maintaining stability; 4) Increased discipline; 5) Creating a good working atmosphere and relationship; 6) Increase loyalty, creativity, and participation of teachers and education staff; 7) Increase the level of welfare; 8) Enhance the sense of responsibility for their duties; 9) Improve work efficiency. The results of the descriptive analysis of the basic work experience variables in Kalidoni are as follows.

Table 9. Descriptive Statistics Variables Work motivation in Kalidoni

\begin{tabular}{ll}
\hline$N \quad$\begin{tabular}{l} 
Valid \\
\multicolumn{1}{c}{ Missing }
\end{tabular} & 28 \\
\hline Mean & 0 \\
Median & 60.0698 \\
Std. Deviation & 60.0000 \\
Minimum & 5.33807 \\
Maximum & 51.00 \\
\hline
\end{tabular}

From the table above, it can be stated that the average value is 60 , the median value is 60 , the standard deviation value of 5.3 is a minimum value of 51 and the maximum value is 69 .
Table 10. Frequency Distribution of Basic Work Motivation Variables in Kalidoni

\begin{tabular}{cccccc}
\hline & Frequency & Percent & Valid Percent & $\begin{array}{c}\text { Cumulative } \\
\text { Percent }\end{array}$ \\
\hline \multirow{6}{*}{ Valid } & 2 & 7.1 & 7.1 & 7.1 \\
& 44.00 & 2 & 7.1 & 7.1 & 14.3 \\
46.00 & 2 & 7.1 & 7.1 & 21.4 \\
46.00 & 2 & 10.7 & 10.7 & 32.1 \\
47.00 & 3 & 17.9 & 17.9 & 50.0 \\
& 48.00 & 5 & 10.7 & 10.7 & 60.7 \\
& 49.00 & 3 & 10.7 & 10.7 & 71.4 \\
& 50.00 & 3 & 7.1 & 7.1 & 78.6 \\
& 51.00 & 2 & 10.7 & 10.7 & 89.3 \\
52.00 & 3 & 7.1 & 7.1 & 96.4 \\
53.00 & 2 & 3.6 & 3.6 & 100.0 \\
& 54.00 & 1 & 100.0 & 100.0 & \\
\hline
\end{tabular}

From the table above, it shows that the work motivation of principals who have a very high category amounts to 14 or $50 \%$, the high category amounts to 14 or $50 \%$, the category is quite good at 13 or $29.5 \%$, and the category is 0 or $0 \%$, and a very less category of 0 or $0 \%$. The results of the analysis show that the motivation of the primary school principal in Kalidoni is in the high category.

\subsubsection{The performance of the principal of the Elementary School in Kalidoni}

In this variable, there are four indicators to determine the performance of the principal of a primary school in Kalidoni, namely 1) Quality of work; 2) Promptness (timeliness of completing work); 3) Initiative (initiative in completing work); 4) Capability (ability to complete work); 5) Communication (ability to foster cooperation with other parties). All indicators are contained in 13 questions. The results of the descriptive analysis of the performance variables of elementary school principals in Kalidoni are as follows.

Table 11. Descriptive Statistics of Principal Performance in Kalidoni

\begin{tabular}{ll}
\hline$N \quad \begin{array}{l}\text { Valid } \\
\text { missing }\end{array}$ & 28 \\
\hline Mean & 49.0000 \\
Median & 48.0000 \\
Std. Deviation & 3.37749 \\
Variance & 11.407 \\
Minimum & 44.00 \\
Maximum & 56.00 \\
\hline
\end{tabular}

From the table above, it can be argued that the mean value is 49 , the median value is 48 , the standard deviation value is 3.3 minimum value of 44 and a maximum value of 46 . The data frequency distribution of basic work experience variables in Kalidoni is as follows. 
Table 12. Frequency Distribution Variable Performance of Elementary School Principals in Kalidoni

\begin{tabular}{cccccc}
\hline & & Frequency & Percent & Valid Percent & $\begin{array}{c}\text { Cumulative } \\
\text { Percent }\end{array}$ \\
\hline \multirow{6}{*}{ Valid } & & & 3.6 & 3.6 & 3.6 \\
& 45.00 & 1 & 1.0 .7 & 10.7 & 14.3 \\
46.00 & 3 & 10.7 & 10.7 & 25.0 \\
47.00 & 3 & 10.7 & 10.7 & 35.7 \\
48.00 & 5 & 17.9 & 17.9 & 53.6 \\
& 49.00 & 5 & 17.9 & 17.9 & 71.4 \\
& 52.00 & 3 & 10.7 & 10.7 & 82.1 \\
53.00 & 1 & 3.6 & 3.6 & 85.7 \\
54.00 & 2 & 7.1 & 7.1 & 92.9 \\
56.00 & 2 & 7.1 & 7.1 & 100.0 \\
Total & 28 & 100.0 & 100.0 & \\
\hline
\end{tabular}

From the table above, it shows that the performance of the principal has a very high category of 5 or $17.8 \%$, the high category amounts to 23 or $82.2 \%$, the high enough category is 0 or $0 \%$, the category is 0 or $0 \%$, and very less category of 0 or $0 \%$. The results of the analysis show that the performance of the principal is in a high category, thus the performance of the Principal has been fulfilling to achieve the goals of the school institution towards the good.

\subsection{Data Requirement Test 3.3.1 Normality Test}

The normality test in this study used the Kolmogrov-Smirnov test using SPSS 22.00. The results of the analysis of the normality test in this study can be seen in the following table.

Table 13. Tests of Normality One-Sample KolmogorovSmirnov Test

\begin{tabular}{lll}
\hline & & $\begin{array}{l}\text { Unstandardized } \\
\text { Residual }\end{array}$ \\
\hline$N$ & & 28 \\
Normal Parameters & Mean & .0000000 \\
& Std. Deviation & 1.10498962 \\
Most Extreme Differences & Absolute & .174 \\
& Positive & .174 \\
Test Statistic & Negative & -.121 \\
Asymp. Sig. (2-tailed) & & .174 \\
\hline
\end{tabular}

Test distribution is Normal.

Calculated from data.

Lilliefors Significance Correction.

From the table above, it can be stated that all values are 0.29 greater than 0.05 , thus it can be stated that all data are normally distributed.

\subsubsection{Homogenity Test}

The homogeneity test in this study using the test of homogeneity of variances using SPSS 22.00. with the following assumptions.

Table 14. Test of Homogeneity of Variances

\begin{tabular}{cccc}
\hline Levene Statistic & $d f 1$ & $d f 2$ & Sig. \\
\hline .380 & 3 & 108 & .768 \\
\hline
\end{tabular}

From the results of data analysis using SPSS 22.00, it can be stated that the sig value is greater than the probability value $(0.77450 .05)$ so that the data is considered homogeneous.

\subsubsection{Multicollinearity Test}

The calculation results show the VIF price and tolerance as follows.

Table 15. Multicollinearity Testing Summary

\begin{tabular}{llll}
\hline \multicolumn{4}{c}{ Coefficients } \\
\hline \multirow{3}{*}{ Model } & & \multicolumn{2}{l}{ Collinearity Statistics } \\
\hline 1 & Academic Qualification & .054 & 18.460 \\
& Work experience & .067 & 14.957 \\
& Work motivation & .242 & 4.137 \\
& & & VIF
\end{tabular}

a. Dependent Variable: Performance

From the table above, it can be stated that academic qualifications (X1) VIF $=18,460$, Work experience (X2) VIF = 14,957 and work motivation $(X 3)$ VIF $=4,137$. VIF from the classic assumption test results are still between 1-10 so there is no multicollinearity. Thus, it can be stated that the relationship between the independent variables contained in the model has a perfect or near-perfect relationship

\subsection{Hypotesis Testing Research}

Having stated that the data has met the requirements to be tested. Then the next hypothesis test is done by $t$ test and $F$ test to determine the effect simultaneously and partially.

\subsubsection{The Effect of Academic Qualifications on the Performance of the Principal of a Primary School in the Kalidoni}

The hypothesis is as follows.

There is a significant influence between academic qualifications on the primary school principal performance in Kalidoni. There is no significant effect between the principal's academic qualifications on the primary school principal performance in Kalidoni. The relationship model of academic qualifications on the performance of principals is expressed in the form of a regression equation $Y=40,184+0.633 \mathrm{X} 1$. The significance test of the regression equation can be presented in the following table.

Table 16. Significance of the Effect of Academic Qualifications on the Performance of Elementary School Principals in Kalidoni

\begin{tabular}{|c|c|c|c|c|c|c|}
\hline & \multirow{2}{*}{ Model } & \multicolumn{2}{|c|}{$\begin{array}{l}\text { Unstandardized } \\
\text { Coefficients }\end{array}$} & \multirow{2}{*}{$\begin{array}{c}\text { Standardized } \\
\text { Coefficients } \\
\text { Beta }\end{array}$} & \multirow{2}{*}{$T$} & \multirow{2}{*}{ Sig. } \\
\hline & & $B$ & $\begin{array}{l}\text { Std. } \\
\text { Error }\end{array}$ & & & \\
\hline \multirow{2}{*}{1} & (Constant) & 40.184 & 13.379 & & 3.004 & .006 \\
\hline & $\begin{array}{c}\text { Academic } \\
\text { Qualification }\end{array}$ & .633 & .400 & .645 & 4.584 & .002 \\
\hline
\end{tabular}

Based on the significance test of the academic qualification variable on the performance of principals in Kalidoni, $t_{\text {count }}$ is 
$4,584 \leq t_{\text {table }}$ is 2,055 where the $t_{\text {value }}$ is greater than $t_{\text {table }}$ so $H_{0}$ 1 is accepted so that there is no significant influence between principals' academic supervision of performance headmaster in Kalidoni Elementary School.

3.4.2 Effect of Work Experience on the Performance of the Principal of the Elementary School in Kalidoni

The hypothesis is as follows.

There is a significant effect of work experience on the primary school principal performance in Kalidoni. There is no significant effect between work experience on the primary school principal performance in Kalidoni. The model of the relationship between work motivation and the performance of principals is expressed in the form of a regression equation $Y$ $=10,038+0.594$. X2 The significance test of the regression equation can be presented in the following table.

Table 17. Significance of the Effect of Work Experience on the Performance of Elementary School Principals in Kalidoni

\begin{tabular}{|c|c|c|c|c|c|c|}
\hline \multicolumn{7}{|c|}{ Coefficients $^{a}$} \\
\hline & \multirow{2}{*}{ Model } & \multicolumn{2}{|c|}{$\begin{array}{c}\text { Unstandardized } \\
\text { Coefficients }\end{array}$} & \multirow{2}{*}{$\begin{array}{c}\text { Standardized } \\
\text { Coefficients } \\
\text { Beta }\end{array}$} & \multirow{2}{*}{$T$} & \multirow{2}{*}{ Sig. } \\
\hline & & B & $\begin{array}{l}\text { Std. } \\
\text { Error }\end{array}$ & & & \\
\hline \multirow{2}{*}{1} & (Constant) & 40.184 & 13.379 & & 3.004 & .006 \\
\hline & Pengalaman kerja & .594 & .437 & -.566 & 11.360 & .001 \\
\hline
\end{tabular}

Based on the significance test of work experience variable (X2) on the performance of the principal $(\mathrm{Y})$ in Kalidoni, the value of $t_{\text {count }}$ is $11.36060 \geq t_{\text {table }}$ is 2.055 where $t_{\text {count }}$ is greater than $t_{\text {table }}$ so $\mathrm{Ha} 2$ is accepted so that there is a significant influence between experience work towards the primary school principal performance in Kalidoni.

3.4.3 Effect of Work Motivation on the Primary School Principals Performance in Kalidoni

The hypothesis is as follows. There is a significant effect of work motivation on the primary school principal performance in Kalidoni.There is no significant effect between work motivation on the primary school principal performance in Kalidoni. The model of the relationship between work motivation and the performance of principals is expressed in the form of a regression equation $Y=10,038+0.739$. X3 Test of significance of the regression equation can be presented in the following table.

Table 18. Significance of the Effect of Academic Qualifications on the Implementation of Teacher Administration in Kalidoni

\begin{tabular}{|c|c|c|c|c|c|c|}
\hline \multicolumn{7}{|c|}{ Coefficients $^{a}$} \\
\hline & \multirow{2}{*}{ Model } & \multicolumn{2}{|c|}{$\begin{array}{c}\text { Unstandardized } \\
\text { Coefficients }\end{array}$} & \multirow{2}{*}{$\begin{array}{c}\text { Standardized } \\
\text { Coefficients } \\
\text { Beta }\end{array}$} & \multirow{2}{*}{$t$} & \multirow{2}{*}{ Sig } \\
\hline & & $B$ & $\begin{array}{l}\text { Std. } \\
\text { Error }\end{array}$ & & & \\
\hline \multirow{2}{*}{1} & (Constant) & 40.184 & 13.379 & & 3.004 & .006 \\
\hline & Work Experience & .739 & .247 & .115 & 6.564 & .003 \\
\hline & Dependent Varia & e: Perfor & lance & & & \\
\hline
\end{tabular}

Based on the significance test of work motivation variable (X3) on the performance of the principal $(Y)$ in Kalidoni, $t_{\text {count }}$ is $6,564 \geq t_{\text {table }} 2,055$ where $t_{\text {count }}$ is greater than $t$ table $s o \mathrm{Ha} 3$ is accepted so that there is a significant influence between motivation work towards the primary school principal performance in Kalidoni.

3.4.4 Joint Effect of Academic Qualifications, Work Experience and Work Motivation on the Primary School Principals Performance in Kalidoni

Based on the results of multiple regression tests, the constant value of the regression equation (a) is 10.038 and the independent variable coefficient (b1) is 0.001 and the value (b2) is 0.871 , the regression equation is obtained as follows. $Y$ $=a+b 1 X 1+b 2 X 2+b 3 X 3 Y=10,038+0.633 X 1+0.594 X 2$ $+0.739 \times 3$ That is, the performance of principals has increased positively with academic qualifications, work experience, and work motivation. To find out the truth of hypothesis testing, simulutan testing was carried out using the $\mathrm{F}$ test to determine the effect of variable academic qualifications, work experience and work motivation on the principal performance variable . The testing criteria are as follows. If the probability value (significant) $<0.005$, then $\mathrm{Ho} 3$ is rejected If the probability value (significant) $>0.005$, then $\mathrm{Ho} 3$ is accepted Then for the $\mathrm{F}$ test, the test criteria are as follows. Ha4 is accepted if $F_{\text {count }}>$ $F_{\text {table }} \mathrm{HO} 0$ is accepted if $F_{\text {count }} \leq F_{\text {table. }}$. The research hypothesis is as follows. Ha4: There is a significant influence jointly between academic qualifications, work experience, and work motivation on the performance of the principal in the Kalidoni Elementary School. There is no significant effect jointly between academic qualifications, work experience, and work motivation on the performance of the principal. in the Kalidoni Elementary School. The results of multiple regression analysis can be seen in the following table.

Table 19. The results of multiple regression analysis $X 1, X 2$ and $X 3$ against $Y$

\begin{tabular}{|c|c|c|c|c|c|c|}
\hline \multicolumn{7}{|c|}{ ANOVA $^{b}$} \\
\hline & Model & $\begin{array}{l}\text { Sum of } \\
\text { Squares }\end{array}$ & $D f$ & $\begin{array}{l}\text { Mean } \\
\text { Square }\end{array}$ & $F$ & Sig. \\
\hline \multirow{4}{*}{1} & Regression & 901.824 & 2 & 450.912 & 155.189 & $.000^{\mathrm{b}}$ \\
\hline & Residual & 116.222 & 40 & 2.906 & & \\
\hline & Total & 1018.047 & 42 & & & \\
\hline & a. Predictors & : (Constant) & $\begin{array}{l}\text { ork ex } \\
\text { ualific }\end{array}$ & $\begin{array}{l}\text { ience, Moti } \\
n\end{array}$ & ation, Acad & \\
\hline & b. Dependent & ariable: Per & nance & & & \\
\hline
\end{tabular}

From the Anova test above, obtained $\mathrm{F}_{\text {count }}$ of 155,189 with a significance level of $0,000<$ probability value $\alpha 0,05$ while $F_{\text {table }}$ corresponds to the significance level of 0.05 (3.24) of 3.01 so that $F_{\text {count }}>F_{\text {table }}(155,189>3,01)$ so that $H_{0} 3$ is rejected, meaning that there is a significant effect together between academic qualifications, work experience and work motivation on the performance of the principal of the Kalidoni Sub-district. To find out how much influence the independent variables on the dependent variable simultaneously can be seen in the following summary model table. 
Table 20. Coefficient of Termination

\begin{tabular}{ccccc}
\hline \multicolumn{5}{c}{ Model Summary } \\
\hline Model & $R$ & $R$ Square & $\begin{array}{c}\text { Adjusted } R \\
\text { Square }\end{array}$ & $\begin{array}{c}\text { Std. Error of the } \\
\text { Estimate }\end{array}$ \\
\hline 1 & $.941^{\mathrm{a}}$ & .886 & .880 & 1.70457 \\
\hline
\end{tabular}

a. Predictors: (Constant), Variabel X2, X1

Based on the table, the $R$ squere value of 0.886 can be obtained, so the reflected coefficient is $88.6 \%$ so it can be concluded that the influence of academic qualifications, work experience and work motivation on the performance of primary school principals in Kalidoni together is $88,6 \%$ and the remaining $11.4 \%$ influenced by other factors not examined in this study. As for the results of the whole variable I hypothesis test, it can be stated that there is a significant influence between all the dependent variables on the independent variables in this study. The explanation is as follows. The first hypothesis test is based on the significance test of the academic qualification variable on the performance of the principal in Kalidoni. The $t_{\text {value }}$ is $4,584 \leq t$ table is 2,055 where the $t_{\text {count }}$ is greater than $t_{\text {table }}$ so $\mathrm{H}_{0} 1$ is accepted so that there is no significant effect the principal of the school principal's performance in the Kalidoni Elementary School. Thus, the standard of the academic qualification of a principal must be improved in quality and quantity. From the results of this hypothesis test, it can be stated that academic qualifications can encourage the quality of the performance of a principal. Thus, the higher the academic qualifications, the better the quality of the performance of a school principal. With good performance, a school principal will be able to manage and direct the school institution he leads towards the effectiveness and efficiency through the policies and direction of his vision and mission. As stated by Purnama (2016) in the results of his research stating that the factors that support and also hinder in human resource management, one of them is the principal. Schools must be well managed so that good performance will be achieved by school goals can be achieved, and the quality of graduates will increase. Thus, the success of the school in achieving its vision, mission, and goals is strongly influenced by the competence and capacity of the school principal in managing human resources as the operational actors or implementers of the tasks in the school. Then the results of research from Subarino et al (2012) which states that school leaders play a role in setting goals and organizational justice in schools. The stated goals affect the attitudes or answers of the teacher to the work, namely the next organizational justice can provide meaningful achievement and school effectiveness. Increasing academic qualifications is also considered very important if you look at the breadth of managerial aspects of a school principal. As the results of research conducted by Agus (2010) which states that the principal managerial competencies include very broad aspects ranging from preparing school planning, developing school organizations, empowering school resources, to carrying out supervision of the implementation of school activities in accordance with applicable supervision standards. The many aspects in these competencies require the ability of the principal to always develop. One way for a principal to develop himself is to improve his academic qualifications. The second hypothesis test is the work experience variable (X2) on the performance of the principal $(Y)$ in Kalidoni, the value of $t_{\text {count }}$ is $11,360 \geq t$ table is 2.055 where $t_{\text {count }}$ is greater than $t_{\text {table }}$ so $\mathrm{Ha} 2$ is accepted between work experience and the primary school principal performance in Kalidoni. From the results of this hypothesis test, it can be stated that the work experience of the school principal has a good impact on the quality of work of the principal. Then for the next variable, there is an influence between the work experience of the principal on his performance. This result states that the more experience the principal has, the better the performance will be. The results of this study are supported by research conducted by Suyud (2015) with the results of research stating that in order for schools to improve their quality of education, the appointment of school principals needs to be regulated with a requirement and mechanism that can support the realization of a quality education system. Some essential things that need to be considered one of them is a minimal experience. Then the results of the third hypothesis test, namely work motivation variable $(X 3)$ on the performance of the principal $(Y)$ in Kalidoni, obtained the value of $t_{\text {count }}$ of $6,564 \geq t_{\text {table }}$ of 2,055 where $t_{\text {count }}$ is greater than $t_{\text {table }}$ so Ha3 is accepted so that there is influence significant between work motivation towards the primary school principal performance in Kalidoni. Work motivation is one of the factors that determine a person's performance. Thus, the magnitude or effect of motivation on a person's performance depends on how much intensity the motivation is given. This result is supported by the most fundamental theory for the importance of leadership practices, namely the theory of human motivation based on goals (Locke, Latham and Eraz, 1988). According to the theory, people are motivated by forced goals so that the planned program is achieved. With the purpose of being able to help people feel their jobs and enable them to gain self-identity in their work. Then the opinion of Uno (2010) that motivation is a process that is carried out to move the principal so that their behavior can be directed at tangible efforts to achieve predetermined educational goals. The main benefit of work motivation is creating work passion, so that work productivity increases. This is supported by research conducted by research conducted by Putra (2017) with the results of research which states that Work motivation has a positive and significant effect on the performance of principals at $14.40 \%$. This means that good Work Motivation has an impact on the Principal's Performance. The principal's internal motivation must be improved because if the principal's internal motivation is good then the motivation to work in school will be much better, thus the Principal's performance will be better. Then for the results of the fourth hypothesis test states that there is a significant effect jointly between academic qualifications, work experience and work motivation on the performance of the principal of Kalidoni Sub-district. From the ANOVA test obtained $F_{\text {count }}$ of 155,189 with a significance level of 0,000 <probability value a 0.05 while $F_{\text {table }}$ corresponds to the significance level of 0.05 (3.24) of 3.01 so that the $F_{\text {count }}>F_{\text {table }}$ $(155,189>3.24)$ so that Ho3 is rejected. To find out how much influence the independent variable on the simulutan dependent variable obtained the $R$ squere value of 0.886 thus the reflected coefficient was $88.6 \%$ so it can be concluded that the influence of academic qualifications, work experience and work motivation on the performance of the primary school principals in Kalidoni together at $88.6 \%$ and the remaining $11.4 \%$ influenced by other factors not examined in this study. In particular, this finding confirms that to improve the performance of principals it may only be optimal if the factors of the principal's academic qualifications, work experience, 
and work motivation are increased together. The synergy between the principal's academic qualifications, work experience, and work motivation has a big influence on the quality of the principal's performance. This can be seen from the results of statistical tests on each of the research variables $\mathrm{X} 1, \mathrm{X} 2$, and $\mathrm{X} 3$ on the dependent variable $\mathrm{Y}$, both individually and jointly contributing positively to the performance of the head of the Elementary School in Kalidoni, Palembang. Thus it can be stated that the performance of the principal to achieve the objectives of the effectiveness and efficiency of the educational institutions he manages requires academic qualifications, work experience and high motivation. In other words, that in order to achieve school effectiveness, a leader who is able to think effectively is needed. From the results of the above research, it can be stated that the principal's performance is strongly influenced by academic qualifications, work experience and work motivation of the principal. The performance of principals based on high academic qualifications, work experience and work motivation will have a major impact on the management of school resources and improving the quality of schools. The results of this study are supported by research conducted by Hartini (2012) with the results of the study showing that there are significant and partial influences between academic qualifications, work experience and work motivation on the performance of Elementary School Principals in Wiradesa District, Pekalongan Regency. The amount of influence of academic qualifications is $32 \%$, work experience $(42.9 \%)$, work motivation $(35.2 \%)$, and influence together $(59.7 \%)$. The results of this hypothesis test are supported by research conducted by Sobri (2017) with the results of research that suggest that the role of the principal as a leader in his school has an important meaning in creating an effective school. There are several roles that are attached to the principal, namely administrators, supervisors, managers, leaders, and educators. There are four effective roles of principals: providers of resources, sources of learning, communicators, their presence is always visible. Effective schools are certainly led by effective school principals. Then supported by research from Santosa (2018) with the results of a study stating that managerial effectiveness in schools is the ability of schools to realize their goals. The purpose or direction of the school is often also known as the school's vision. At present many schools have not been able to realize their vision to the fullest. One of them is caused by leadership factors. School leaders or school principals must be able to become the dominant factor in achieving school vision. To realize managerial effectiveness in schools, it can be done by principals by increasing integrity and instilling it in subordinates, increasing motivation and becoming extrinsic motivators for the school community and providing rewards and building trust in subordinates.

\section{ConCLUSION}

Based on data analysis and hypothesis testing, conclusions can be taken as follows. Based on the significance test there is a significant effect between the principal's academic qualifications on the performance of the principal in the Kalidoni Elementary School. There is a significant influence between work experience on the primary school principal performance in Kalidoni. There is a significant influence between work motivation on the primary school principal performance in Kalidoni. Then there is a significant effect together between academic qualifications, work experience and work motivation on the performance of the principal of Kalidoni Sub-district. From the ANOVA test obtained $F_{\text {count }}$ of 155,189 with a significance level of $0,000<$ probability value $\alpha$ 0.05 while $F_{\text {table }}$ corresponds to the significance level of 0.05 (3.24) of 3.01 so that the $F_{\text {count }}>F_{\text {table }}(155,189>3.24)$ so that $\mathrm{H}_{0} 3$ is rejected. The influence of the independent variable on the simulutan dependent variable obtained $R$ squere value of 0.886 so the reflected coefficient is $88.6 \%$ so it can be concluded that the influence of academic qualifications, work experience and work motivation on the performance of primary school principals in Kalidoni together -same as $88.6 \%$ and the remaining $11.4 \%$ influenced by other factors not examined in this study.

\section{REFERENCES}

[1] Agus, N, P. (2010). Strategi Pengembangan Kompetensi Manajerial Kepala Sekolah [Strategy of Developing Principal Managerial Competence]. Jurnal Administrasi Pendidikan UMY. Vol VI, No 2. 55-63

[2] Akdon. (2004). Dasar Dasar Manajemen Basics of Management]. Yokyakarta: Gadjah Mada University Press.

[3] Andriani, S., Kesumawati, N., \& Kristiawan, M. (2018). The Influence Of The Transformational Leadership And Work Motivation On Teachers Performance. International Journal of Scientific \& Technology Research, 7(7).

[4] Anwaruddin, A. (2006). Pengembangan Model Penilaian Kinerja Pegawai [Development of Employee Performance Assessment Model]. Jurnal IImu Administrasi. Vol. 3, No. 4. Halaman 268-279.

[5] Bashor, C. (2007). Pengaruh Motivasi Kerja terhadap Kinerja Karyawan PTSemen Gresik, Tuban dengan Variabel Moderator Etos Kerja Spiritual [Effect of Work Motivation on PTSemen Gresik Employee Performance, Tuban with Moderate Spiritual Work Ethics Variables]. Jurnal Manajemen, Akuntansi dan Bisnis. Vol. 5, No. 3. Halaman 362-371.

[6] Daryanto. (2011). Kepala Sekolah Sebagai Pemimpin Pembelajaran [Principal as Learning Leader]. Yogyakarta: Grava Media.

[7] Ditjen PMPTK. (2008). Administrasi dan Supervisi Pendidikan [Educational Administration and Supervision]. Bandung: Remaja.

[8] Djafar, $\mathrm{H}$ dan Nurhafizah N. (2018). Pengaruh Motivasi Kepala Sekolah Terhadap Kinerja Guru Dan Pegawai Di Smk Muhammadiyah 3 Makassar [The Effect of School Principal Motivation on the Performance of Teachers and Employees at Muhammadiyah 3 Makassar Middle School]. Jurnal Idaarah, vol. 2, no. 1: 24-36.

[9] Gomes. (2001). Manajemen Sumber Daya Manusia [Human Resource Management]. Yogyakarta: Andi offset.

[10] Hamalik, O. (2011). Proses Belajar Mengajar [Teaching and learning process]. Jakarta: Bumi Aksara

[11] Hartini, S. (2012). Pengaruh Kualifikasi Akademik, Pengalaman Kerja Dan Motivasi Kerja Terhadap Kinerja Kepala Sekolah Dasar Se Kecamatan Wiradesa Kabupaten Pekalongan [The Influence of Academic Qualifications, Work Experience and Work Motivation on the Performance of the Principal of the 
District of Wiradesa, Pekalongan Regency]. JMP, Volume 1 Nomor 3: 331-344

[12] Hasibuan, M. (2000). Manajemen Sumber Daya Manusia [Human Resource Management]. Edisi. Revisi.Jakarta: PT Bumi Aksara.

[13] Irmayani, H., Wardiah, D., \& Kristiawan, M. (2018). The Strategy of SD Pusri In Improving Educational Quality. International Journal of Scientific \& Technology Research, 7(7).

[14] Kamidin, M. (2010). Pengaruh Kompetensi terhadap Prestasi Kerja Pegawai Sekretariat Daerah Kabupaten Bantaeng [The Effect of Competence on the Work Performance of Bantaeng District Secretariat Employees]. Jurnal Economic Resources. Vol. 11, No. 30: 79-9.

[15] Kesumawati, N. \& Aridanu, I. (2017). Statistik Parametrik Penelitian Pendidikan [Parametric Statistics on Educational Research]. Depok: Rajagrafindo Persada.

[16] Kristiawan, M., Safitri, D., \& Lestari, R. (2017). Manajemen Pendidikan [Educational Management]. Yogyakarta: Deepublish.

[17] Kristiawan, M., Yuniarsih, Y., \& Fitria, H. (2019). Supervisi Pendidikan [Educational Supervision]. Bandung: Alfabeta

[18] Kunandar (2007). Guru Profesional Implementasi Kurikulum Tingkat Satuan Pendidikan (KTSP) [Professional Teachers Implement Educational Unit Level Curriculum (KTSP)]. Bandung: Karya Bangsa.

[19] Lian, B., Kristiawan, M., \& Fitriya, R. (2018). Giving Creativity Room To Students Through The Friendly School's Program. International Journal of Scientific \& Technology Research, 7(7).

[20] Locke, E. A., Latham, G. P. \& Erez, M. (1988). The Determinants of Goal Commitment. Academy of Management Review, 13(1), pp. 23-39.

[21] Mangkunegara, A, P. (2004). Manajemen Sumber Daya Manusia Perusahaan [Company Human Resource Management]. Bandung: Remaja Rosdakarya.

[22] Mangkunegara, A.P. (2001). Manajemen Sumber Daya Perusahaan [Company Human Resource Management]. Bandung: PT. Remaja Rosdakarya.

[23] Marno. (2008). Manajemen dan Kepemimpinan Pendidikan [Education Management and Leadership]. Islam. Bandung: PT Refika Aditama.

[24] Miarso Y. (2008). Peningkatan Kualifikasi Guru dalam Perspektif Teknologi Pendidikan [Increasing Teacher Qualifications in the Educational Technology Perspective]. Jurnal Pendidikan Penabur 7 (10): 6676.

[25] Mulyani, A. (2012). Pengaruh Kinerja Kepala Sekolah Dan Kinerja Guru Terhadap Mutu Pembelajaran Pada Smk Sekabupaten Purwakarta [Effect of School Principal Performance and Teacher Performance on Learning Quality in Middle School Purwakarta Regency].Jurnal Adminisistrasi Pendidikan Vol.XIV No.1: 86-92.

[26] Mulyasa, E. (2009). Praktik Penelitian Tindakan Kelas [Classroom Action Research Practices]. Bandung: PT. Remaja Rosda Karya.

[27] Mulyasa, E. (2011). Manajemen dan Kepemimpinan Kepala Sekolah [Principal Management and
Leadership]. Jakarta: Bumi Aksara.

[28] Murtiningsih, M., Kristiawan, M., \& Lian, B. (2019). The Correlation Between Supervision of Headmaster and Interpersonal Communication With Work Ethos of the Teacher. European Journal of Education Studies.

[29] Musfiqon. (2012). Pengembangan Media dan Sumber Media Pembelajaran [Media Development and Learning Media Sources]. Jakarta: T. Prestasi Pustakaraya.

[30] Muzakar. (2014). Kinerja Kepala Sekolah Dalam Meningkatkan Mutu Lulusan Pada Madrasah Tsanawiyah Negeri Meureubo [The Principal's Performance in Increasing the Quality of Graduates at the Meureubo State Tsanawiyah Madrasah]. Jurnal Islam Futura. Vol 14. No 1. 110-133.

[31] Nawawi, H. (1985). Metodologi Penelitian Bidang Sosial [Social Research Methodology]. Semarang: IKIP Semarang Press.

[32] Nitisemito,A, S. (2009). Manajemen Personalia [Personnel Management]. Edisi Revisi, Jakarta: Ghalia Indonesia.

[33] Permendiknas No 13 Tahun 2007 Tentang Standar Kepala Sekolah/Madrasah [Government Regulation of Standard Qualification for Principal.

[34] Purnama, J, B. (2016). Optimalisasi Manajemen Sumber Daya Manusia Dalam Upaya Peningkatan Mutu Sekolah [Optimization of Human Resource Management in School Quality Improvement Efforts]. Jurnal Manajemen Pendidikan Vol 12 No2 : 27-36.

[35] Purwanto, N. (2001). Prinsip Prinsip dan Teknik Evaluasi Pengajaran [Principles of Principles and Teaching Evaluation Techniques]. Bandung: PT. Remaja Rosda Karya.

[36] Putra, E. (2017). Pengaruh Supervisi Manejerial Dan Motivasi Kerja Terhadap Kinerja Kepala Sekolah Pada Sekolah Dasar Negeri Menurut Persepsi Guru SeKota Padang Panjang [Effect of Managerial Supervision and Work Motivation on the Performance of Principals in Public Elementary Schools According to Teachers' Perceptions in the City of Padang Panjang].

Jurnal al-Fikrah, Vol. V, No. 2.

[37] Rahayu, T. (2011). Pengaruh kualifikasi akademik, pelatihan, pengalaman mengajar, dan persepsi guru tentang penerapan pembelajaran IPS secara terpadu terhadap kinerja guru IPS terpadu di SMP Negeri Sekota Blitar [Effect of academic qualifications, training, teaching experience, and teacher perceptions on the application of social studies learning in an integrated manner to the performance of integrated social studies teachers in Blitar City Middle School]. Abstrak. (Onlilne).http://library.um.ac.id

[38] Renata, R., Wardiah, D., \& Kristiawan, M. (2018). The Influence of Headmaster's Supervision And Achievement Motivation On Effective Teachers. International Journal of Scientific \& Technology Research, 7(4).

[39] Sa'diyah, C. (2013). Pengaruh Pengalaman Kerja, Motivasi Intrinsik dan kepuasan kerja karyawan terhadap kinerja karyawan Depo Pelita PT Pelita Satria Perkasa Sukoraja [nfluence of Work Experience, Intrinsic Motivation and employee job satisfaction on employee performance of Pelita Pelo 
PT Pelita Satria Perkasa Sukoraja]. Jurnal Bisnis Manajemen, Volume VII, No 1; 1-13

[40] Santosa, H, F. (2018). Efektivitas Manajerial Kepala Sekolah Dalam Mewujudkan Visi Misi Sekolah [Managerial Effectiveness of Principals in Realizing the School's Vision and Mission. Hikmah: Jurnal Pendidikan Islam Vol. 7, No. 1: 131-148.

[41] Sardiman, A.M. (2011). Interaksi dan Motivasi Belajar Mengajar [Interaction and Motivation in Teaching and Learning]. Jakarta: Rajawali Press.

[42] Sarina., Kristiawan, M., \& Wardiah, D. (2019). Module Development the Utilization of Patchwork Fabric As Teaching Materials Crafts on the Subjects of Craft and Entrepreneurship For High School Students. International Journal of Scientific \& Technology Research, 8(5).

[43] Silaen, U. (2012). Pengaruh Kepemimpinan Partisipatif Kepala Sekolah, Pengalaman Kerja, Dan Tim Kerja Terhadap Kinerja Guru Di Smp Katolik Kota Medan [The Effect of Principal Participatory Leadership, Work Experience, and Work Teams on Teacher Performance in Catholic Middle Schools in Medan City]. (Online). http://digilib.unimed.ac.id/UNIMED-Master-1250/1250.

[44] Silalahi, B Y. (2007). Kontribusi Gaya Kepemimpinan Transformasional dan Budaya Organisasi dengan Motivasi Kerja Karyawan PT. X [ontributions of Transformational Leadership Style and Organizational Culture with Work Motivation at PT. X]. Jurnal Penelitian Psikologi. Vol. 12, No. 2. Halaman 147156.

[45] Simbolon, M. (2012). Pengaruh Kualifikasi Akademik Guru Dan Kompetensi Profesional Terhadap Kinerja Guru Atas Dasar Penilaian Kepala Sekolah (Sensus pada Guru Mata Pelajaran Kesenian Tingkat Sekolah Menengah Atas di Kota Binjai Sumatera Utara) [The Influence of Academic Qualifications of Teachers and Professional Competencies on Teacher Performance Based on Principal Assessment (Census of High School Level Art Subject Teachers in Binjai City, North Sumatra)].

http://repository.upi.edu/tesisview.php?no_tesis=2043

[46] Sobri, Y, A. (2017). Kepemimpinan Kepala Sekolah Dasar

Dalam Menciptakan Sekolah Yang Efektif [Primary School Leadership in Creating Effective Schools]. Jurusan Administrasi Pendidikan FIPUniversitas Negeri Malang: 1-18

[47] Soetjipto. (2007). Pengaruh Faktor Pendidikan, Pelatihan, Motivasi dan Pengalaman Kerja terhadap Kinerja Kepala Desa (Studi pada Kepala Desa di Kecamatan Pakis dan Tumpang Malang) [Effect of Education, Training, Motivation and Work Experience Factors on the Performance of Village Heads (Study on Village Heads in Pakis and Overlapping Districts of Malang)]. Jurnal Aplikasi Manajemen. Vol. 5, No. 1: 159-165

[48] Subarino, A., Ali, J., \& Ngang, K, T. (2012). Penetapan Tujuan Dan Keadilan Organisasi Serta Dampaknya Terhadap Efektivitas Sekolah: Sebuah Kajian Eksplorasi [Determination of Organizational Goals and Justice and Their Impact on School Effectiveness: An Exploration Study]. Jurnal
Manajemen Pendidikan Vol VII No 1: 52-66.

[49] Sudharto. (2012). Pengaruh Budaya Organisasi Sekolah, Pengalaman Kerja, dan Kompensasi Terhadap Kepuasan, Motivasi Kerja, Dan Kinerja Kepala SMA Se Eks Karesidenan Semarang [The Influence of School Organizational Culture, Work Experience, and Compensation on Satisfaction, Work Motivation, and Performance of Head of Senior High School in Ex-Residency Semarang]. Artikel. PPs Universitas Negeri Semarang.

[50] Sugiyono. (2009). Metode Penelitian Kuantitatif dan $R$ dan $D$ [Quantitative Research Methods and $R$ and D]. Bandung : Alfabeta.

[51] Suhardi. (2012). Pengaruh Peran Aktif Komite Sekolah dan Kinerja Kepala Sekolah terhadap Mutu SMK di Kabupaten Pemalang [Effect of the Active Role of School Committees and School Principals' Performance on the Quality of Vocational Schools in Pemalang District]. Jurnal Manajemen Pendidikan. Vol. 1, No. 1. Halaman 96-101

[52] Sujiono, B. (2010). Bermain Kreatif Berbasisi Kecerdasan Jamak [Creative Play Based on Plural Intelligence]. Jakarta: Indeks.

[53] Suyud. (2015). Telaah Profesionalisasi Jabatan Kepala Sekolah [Review the Professionalization of the Principal's Position]. Jurnal Administrasi Pendidikan Vol 1 No 1: 37-46

[54] Syafrudin. (2009). Kebidanan Komunitas [Midwifery Community]. Jakarta : EGC.

[55] Tobari., Kristiawan, M., \& Asvio, N. (2018). The Strategy of Headmaster on Upgrading Educational Quality In Asean Economic Community (AEC) Era. International Journal of Scientific \& Technology Research, 7(4).

[56] Uno, B, H. (2010). Model Pembelajaran Menciptakan Proses Belajar Mengajar Yang Kreatif [Learning Models Create Creative Teaching and Learning Processes]. Jakarta: Bumi Aksara.

[57] Wandasari, Y., Kristiawan, M., \& Arafat, Y. (2019). Policy Evaluation of School's Literacy Movement on Improving Discipline of State High School Students. International Journal of Scientific \& Technology Research, 8(4).

[58] Wardayati, S, M. (2008). Pengaruh Individual Rank, Pengalaman Kerja, dan Skala Perusahaan Terhadap Profesionalisme Auditorium Intern (Studi Empiris terhadap Para Auditor Intern Emiten pada Sektor Manufaktur di Bursa Efek Jakarta) [Effect of Individual Rank, Work Experience, and Company Scale on Internal Auditorium Professionalism (Empirical Study of Issuers Internal Auditors in the Manufacturing Sector at the Jakarta Stock Exchange)]. Jurnal Akuntansi Universitas Jember. Vol. 6, No. 1: 1-24 